\title{
Lembaga Constitusional Importance Dalam Sistem Ketatanegaran Indonesia
}

\author{
Institutional Importance in the Indonesian Rigidity System
}

\author{
Madon Yanuar \\ madon.yanuarl@gmail.com
}

Fakultas Hukum Universitas Lampung

Submitted: Mar 11, 2020; Reviewed: Mar 31, 2020; Accepted: Apr 17, 2020

\begin{tabular}{|c|c|}
\hline Info Artikel & Abstrak \\
\hline $\begin{array}{l}\text { Kata Kunci: Lembaga Negara; Importance; } \\
\text { Ketatanegaraan. } \\
\text { Keywords: State Institutions; Importance; State } \\
\text { Administration. } \\
\text { DOI: } \\
\text { https://doi.org/10.25041/constitutionale.v1il.2013 }\end{array}$ & $\begin{array}{l}\text { Terbentuknya lembaga-lembaga } \\
\text { khusus yang diatur dengan undang- } \\
\text { undang ternyata kedudukannya } \\
\text { memiliki derajat yang sama dengan } \\
\text { lembaga yang diatur dalam } \\
\text { konstitusi (constitusional } \\
\text { importance). Tujuan penulisan ini } \\
\text { untuk mengetahui urgensi } \\
\text { keberadaan lembaga negara khusus } \\
\text { yang memiliki constitusional } \\
\text { importance dalam sistem } \\
\text { ketatanegaran Indonesia, dalam hal } \\
\text { ini lembaga negara tersebut adalah } \\
\text { Komnas HAM dan KPK. Metode } \\
\text { penulisan yang digunakan adalah } \\
\text { menggunakan penelitian hukum } \\
\text { normatif. Hasil dari pembahasan } \\
\text { menggambarkan bahwa munculnya } \\
\text { lembaga lembaga negara baru yang } \\
\text { diatur dengan undang-undang yakni } \\
\text { sebagai lembaga fungsional yang } \\
\text { menangani suatu permasalahan } \\
\text { dalam ruang lingkup mereka } \\
\text { masing-masing. Kesimpulannya }\end{array}$ \\
\hline
\end{tabular}


bahwa untuk mengatasi kompleksitas persoalan yang muncul dimasyarakat. Rekomendasi dalam penulisan ini berupaya agar lembaga-lembaga yang memiliki derajat yang sama dengan lembaga yang ada dikonstitusi agar dicantumkan juga dalam konstitusi demi memperkuat kedudukan dan kewenangannya.

Abstract
The formation of special institutions
regulated by law has the same
status as those regulated in
constitution (constitutional
importance). The purpose of this
paper is to determine the urgency of
the existence of a special state
institution that has a constitutional
importance in Indonesia's strictness
system, in this case the state
institutions are the National Human
Rights Commission and the KPK.
The writing method used is to use
normative legal research. The
results of the discussion illustrate
that the emergence of a new state
institution that is regulated by law,
namely as a functional institution
that handles a problem within their
respective scope. The conclusion is
that to overcome the complexity of
problems that arise in society. The
recommendation in this writing
seeks to ensure that institutions
which have the same degree as
existing institutions are constituted
to be included in the constitution in
order to strengthen their position
and authority.




\section{A. Pendahuluan}

Hierarki atau kedudukan suatu lembaga negara terletak pada pengaturan dari lembaga negara itu sendiri secara peraturan perundang-undangan yang berlaku. ${ }^{1}$ Lembaga negara di Indonesia secara pengaturannya terbagi menjadi beberapa bentuk, yakni lembaga negara yang diatur dan dibentuk oleh undang-undang dasar adalah organ konstitusi, lembaga negara yang diatur dan dibentuk oleh undang-undang adalah organ undang-undang, sedangkan lembaga negara yang dibentuk berdasarkan keputusan Presiden maka derajat perlakuan hukum terhadap pejabat yang duduk di dalamnya begitu juga dengan lembaga yang dibentuk pada tingkatan peraturan daerah. ${ }^{2}$ Lembaga negara yang kedudukannya pada tingkat konstitusi adalah Presiden, Wakil Presiden, Dewan Perwakilan Rakyat (DPR), Dewan Perwakilan Daerah (DPD), Majelis Permusyawaratan Rakyat (MPR), Mahkamah Konstitusi (MK), Mahkamah Agung (MA) dan Badan Pemeriksa Keuangan (BPK). ${ }^{3}$ Kewenangan lembaga negara di atas diatur langsung dalam konstitusi yakni undang-undang dasar dan dikhususkan lagi dalam undang-undang, walaupun pada pengangkatan anggotanya ditetapkan melalui keputusan presiden sebagai pejabat administrasi negara yang tertinggi. ${ }^{4}$ Sedangkan lembagalembaga negara yang memiliki derajat kepentingan (constutisional inportance) yang sama dengan lembaga-lembaga negara yang dimaksudkan dalam konstitusi yakni Komisi Nasional Hak Asasi Manusia (Komnas HAM), Komisi Pemberantasan Tindak Pidana Korupsi (KPK) dan lain-lain. ${ }^{5}$ Walaupun lembaga negara tersebut tidak disebutkan secara eksplisit dalam Undang-Undang Dasar tahun 1945, namun lembaga-lembaga negara tersebut memiliki constitusional importance pada sistem konstitusional berdasarkan Undang-Undang Dasar tahun $1945 .^{6}$

Pasal 24 ayat (3) Undang-Undang Dasar Negara Republik Indonesia Tahun 1945 membuka peluang bagi lembaga-lembaga negara lainnya yang fungsinya berkaitan dengan kekuasaan kehakiman yang tidak dijelaskan secara eksplisit dalam Undang-Undang Dasar tahun 1945. ${ }^{7}$ Pasal 24 ayat (3) menyebutkan bahwa "Badan-badan lain yang fungsinya berkaitan dengan kekuasaan kehakiman diatur dalam undang-undang”. Kekuasaan kehakiman disini yang dimaksudkan seperti Mahkamah Agung (MA), Mahkamah Konstitusi (MK), Komisi Yudisial (KY) dan Kepolisian Negara yang diatur dengan Undang-Undang Dasar tahun $1945 .{ }^{8}$ Ketentuan dari badan-badan lain artinya masih ada beberapa lagi lembaga negara yang fungsinya berkaitan dengan kekuasaan kehakiman yaitu fungsi penyelidikan, penyidikan dan penuntutan. ${ }^{9}$ Sistem ketatanegaraan Indonesia pada saat ini mengenal 4 (empat) kekuasaan yang berkedudukan setara yakni Eksekutif, Legislatif, Yudisial dan lembaga negara khusus seperti Komisi Nasional Hak Asasi Manusia (Komnas HAM), Komisi

\footnotetext{
${ }^{1}$ Manan Sailan, "Istilah Negara Hukum Dalam Sistem Ketatanegaraan Republik Indonesia," Istilah Negara Hukum Dalam Sistem Ketatanegaraan Republik Indonesia 40, no. 2 (2011): 228-35, https://doi.org/10.14710/mmh.40.2.2011.228-235.

${ }^{2}$ Idul Rishan, "Relevansi Hak Angket Terhadap Komisi Negara Independen," Dialogia Iuridica: Jurnal Hukum Bisnis Dan Investasi 10, no. 1 (2018): 44-64, https://doi.org/10.28932/di.v10i1.1031.

${ }^{3}$ Efriza, "Relasi Kekuasaan Presiden Dan DPR Dalam Sistem Presidensial Power Relations President And Parliament In The Presidential System," Jurnal Kajian Politik Dan Masalah Pembangunan, 2016.

${ }^{4}$ Ibid, hlm. 44.

${ }^{5}$ Rizki Ramadani, “Lembaga Negara Independen Di Indonesia Dalam Perspektif Konsep Independent Regulatory Agencies," Jurnal Hukum Ius Quia Iustum 27, no. 1 (2020): 169-92, https://doi.org/10.20885/iustum.vol27.iss1.art9.

${ }^{6}$ Retno Mawarini Sukmariningsih, "Penataan Lembaga Negara Mandiri Dalam Struktur Ketatanegaraan Indonesia," Mimbar Hukum - Fakultas Hukum Universitas Gadjah Mada 26, no. 2 (2014): 194-204, https://doi.org/10.22146/jmh.16039.

7 Indra Rahmatullah and Rizza Zia Agusty, "Memperkuat Hubungan Antar Lembaga Negara Dalam Bingkai Negara Hukum," SALAM: Jurnal Sosial Dan Budaya Syar-I 3, no. 2 (2016): 231-44, https://doi.org/10.15408/sjsbs.v3i2.7856.

${ }^{8}$ HM. Thalhah, "Teori Demokrasi Dalam Wacana Ketatanegaraan Perspektif Pemikiran Hans Kelsen," JURNAL HUKUM IUS QUIA IUSTUM 16, no. 3 (2009): 413-22, https://doi.org/10.20885/iustum.vol16.iss3.art6.

9 Jimly Asshiddiqie, Perkembangan dan Konsolidasi Lembaga Negara Pasca Reformasi, Jakarta: Sinar Grafika, 2012, hlm. 89.
} 
Pemberantasan Tindak Pidana Korupsi (KPK) yang diatur dengan undang-undang dan memiliki constitusional importance. Rumusan masalah dalam penelitian yakni menggambarkan salah satu lembaga constitusional importance dalam sistem ketatanegaran Indonesia. Penelitian ini menggunakan penelitian hukum normative dengan pendeketan statue approach dan conseptual approach.

\section{B. Pembahasan}

\section{Lembaga Constitutional Importance}

Lembaga constitusional importance merupakan lembaga negara yang bersifat independen yang memiliki kedudukan atau derajat yang sejajar dengan lembaga negara yang ada dalam Undang-Undang Dasar 1945, ${ }^{10}$ walaupun lembaga-lembaga negara tersebut hanya dibentuk dengan produk legislasi atau sebatas undang-undang namun memiliki kedudukan yang sejajar demi terlaksana fungsi check and belances. ${ }^{11}$

Lembaga-lembaga tersebut yakni: ${ }^{12}$

a) Komisi Yudisial (KY);

b) Bank Indonesia (BI) sebagai Bank sentral;

c) Tentara Nasional Indonesia (TNI);

d) Kepolisian Negara Republik Indonesia (POLRI);

e) Komisi Pemilihan Umum (KPU);

f) Kejaksaan Agung yang kewenangannya belum dijelaskan dalam Undang-Undang Dasar 1945 melainkan hanya dalam undang-undang, namun tetap memiliki constitusional importance yang sama dengan kepolisian;

g) Komisi Pemberantasan Korupsi (KPK) yang juga dibentuk berdasarkan undang-undang namun memiliki sifat constitusional importance berdasarkan Pasal 24 ayat (3) UndangUndang Dasar tahun 1945;

h) Komisi Nasional Hak Asasi Manusia (Komnas HAM) yang sama dibentuk hanya berdasarkan undang-undang namun juga memiliki sifat constitusional importance.

Pertama, Komisi Nasional Hak Asasi Manusia (Komnas HAM). Tujuan dibentuknya Komisi Nasional Hak Asasi Manusia (Komnas HAM) berdasarkan Undang-Undang Nomor 39 Tahun 1999 ini tidaklah jauh berbeda dengan tujuan pembentukan Komnas HAM berdasarkan Keputusan Presiden Nomor 50 Tahun 1993, yaitu:

a) Mengembangkan kondisi yang kondusif bagi pelaksanaan hak asasi manusia sesuai dengan Pancasila, Undang-Undang Dasar 1945 dan Piagam Perserikatan Bangsa-Bangsa, serta Deklarasi Universal Hak Asasi Manusia; ${ }^{13}$

b) Meningkatkan perlindungan dan penegakan hak asasi manusia guna berkembangnya pribadi manusia Indonesia seutuhnya dan kemampuannya berpartisipasi dalam berbagai bidang kehidupan.

Pengaruh dari luar yakni global yang meletakkan isu HAM sebagai isu sentral dalam hubungan internasional sangat berpengaruh terhadap penegakan hukum pada pelanggaran HAM di Indonesia. Indonesia berkomitmen terhadap berbagai kesepakatan atau perjanjian

\footnotetext{
${ }^{10}$ Rika Marlina, "Summary For Policymakers," in Climate Change 2013 - The Physical Science Basis, ed. Intergovernmental Panel on Climate Change, vol. 1 (Cambridge: Cambridge University Press, 2018), 1-30, https://doi.org/10.1017/CBO9781107415324.004.

11 Jailani, "Sistem Demokrasi Di Indonesia Ditinjau Dari Sudut Hukum Dan Ketatanegaraan," Sistem Demokrasi,Sudutt Hukum,Ketatanegaraan 8, no. 1 (2015): 134-47.

${ }_{12}$ Jimly Asshiddiqie, Op. Cit., hlm. 24.

13 Maleha Soemarsono, "Negara Hukum Indonesia Ditinjau Dari Sudut Teori Tujuan Negara," Jurnal Hukum \& Pembangunan 37, no. 2 (2017): 300-322, https://doi.org/10.21143/jhp.vol37.no2.1480.
} 
internasional tentang HAM, namun hal itu pun terlihat dari kebijakan di bidang HAM. Komitmen ini menempatkan Indonesia pada posisi untuk mengakomodasikan berbagai macam kepentingan global artinya bahwa tidak mungkin bila segala aturan hukum nasional, khususnya yang berkaitan dengan HAM di Indonesia dibuat semata-mata berdasar kepentingan negara Indonesia saja tanpa memikirkan kepentingan Internasional. ${ }^{14}$ Hal ini berarti bahwa norma-norma dan standar-standar internasional mengenai HAM menjadi rujukan bagi penyusunan norma dan standar HAM di Indonesia dalam hal ini dilaksanakan oleh Komisi Nasional Hak Asasi Manusia (Komnas HAM). ${ }^{15}$ Komisi Nasional Hak Asasi Manusia (Komnas HAM) memiliki constitusional importance yang sama dengan kejaksaan dan kepolisian, hal tersebut disebabkan karena disetiap negara konstitusional jaminan hak asasi manusia dalam Undang-Undang Dasar dianggap sebagai sesuatu yang mutlak adanya. Jaminan konstitusional hak asasi manusia adalah ciri pokok negara hukum atau paham negara demokrasi konstitusional, ${ }^{16}$ maka dari itu dibentuklah lembaga negara Komisi Nasional Hak Asasi Manusia (KOMNAS HAM) yang dibentuk berdasarkan undang-undang yang pembentukan untuk memajukan dan melindungi hak asasi manusia dalam Undang-Undang Dasar 1945.

Lembaga negara lainnya yang dibentuk pada era reformasi di Indonesia adalah Komisi Pemberantasan Korupsi (KPK). Lembaga ini dibentuk sebagai salah satu bagian agenda pemberantasan korupsi yang merupakan salah satu agenda terpenting dalam pembenahan tata pemerintahan di Indonesia. ${ }^{17}$ Kedudukan lembaga negara dalam sistem ketatanegaraan yang dianut negara Indonesia masih menarik untuk diperbincangkan. Komisi Pemberantasan Korupsi merupakan lembaga bantu negara yang dapat disamakan dengan lembaga negara yang tertuang dalam UUD 1945 karena sama-sama mempunyai struktur organisasi yang sama dengan lembaga negara mempunyai sekjen dan badan Litbang yang dimiliki lembaga negara yang lain sama seperti Komisi Yudisial, dapat dikatakan bahwa kedudukannya secara struktural sederajat dengan Mahkamah Agung dan Mahkamah Konstitusi. Secara fungsional peranannya bersifat penunjang (auxiliary) terhadap lembaga kekuasaan kehakiman. Komisi Yudisial meskipun fungsinya terkait dengan kekuasaan kehakiman, tetapi tidak menjalankan fungsi kekuasaan kehakiman. ${ }^{18}$

Sejatinya, lembaga-lembaga ekstra itu selalu diidealkan bersifat independen dan sering kali memiliki fungsi campuran yang semi legislatif dan regulatif, semi administratif, dan bahkan semi yudikatif. Oleh karena itulah muncul istilah badan badan independen dan berhak mengatur dirinya sendiri (independent and self-regulatory bodies) yang berkembang di berbagai negara. Gejala umum yang sering kali dihadapi oleh negara-negara yang membentuk lembaga-lembaga ekstra itu adalah persoalan mekanisme akuntabilitas, kedudukannya dalam struktur ketatanegaraan, pola hubungan kerjanya dengan kekuasaan pemerintah, kekuasaan membuat undang-undang, serta kekuasaan kehakiman. Pendapat yang menyatakan bahwa keberadaan KPK dalam sistem ketatanegaraan Indonesia adalah ekstra konstitusional karena lembaga ini tidak disebutkan dan diatur dalam UUD 1945 sebagai konstitusi Indonesia adalah

\footnotetext{
${ }_{14}$ Muhammad Amin Putra, "Eksistensi Lembaga Negara Dalam Penegakan Hak Asasi Manusia Di Indonesia," FIAT JUSTISIA:Jurnal Ilmu Hukum 9, no. 3 (April 19, 2016): 256-92, https://doi.org/10.25041/fiatjustisia.v9no3.600.

${ }^{15}$ Ahmad Yani, "Sistem Pemerintahan Indonesia: Pendekatan Teori Dan Praktek Konstitusi Undang-Undang Dasar 1945," Jurnal Ilmiah Kebijakan Hukum 12, no. 2 (2018): 119-35, https://doi.org/10.30641/kebijakan.2018.V12.119-135.

${ }^{16}$ Bustamin Bustamin and Rony Jaya, "Urgensi Checks And Balances Ketatanegaraan Indonesia Dan Islam," JURIS (Jurnal Ilmiah Syariah) 18, no. 2 (2019): 221-32, https://doi.org/10.31958/juris.v18i2.1740.

17 Muhammad Habibi, "Independensi Kewenangan Komisi Pemberantasan Korupsi Pasca Perubahan Undang-Undang Nomor 30 Tahun 2002 Tentang Komisi Pemberantasan Korupsi," Cepalo 4, no. 1 (2020): 38-47, https://doi.org/10.25041/cepalo.v4no1.1962.

18 Fitria, Eksistensi Komisi Pemberantasan Korupsi (KPK) Sebagai Lembaga Negara Penunjang Dalam Sistem Ketatanegaraan Indonesia, hlm. 5.
} 
keliru. Keberadaan atau terbentuknnya KPK walaupun tidak disebutkan dalam UUD 1945, namun keberadaannya secara tegas diatur dalam Undang-Undang No. 19 Tahun 2019 tentang Perubahan Kedua Atas Undang-Undang Nomor 30 Tahun 2002 tentang KPK.

Pendapat tersebut seharusnya memperhatikan bahwa Indonesia sebagai negara hukum mengakui keberadaan KPK sebagai salah satu lembaga negara yang sifatnya konstitusional. ${ }^{19}$ Penjelasan di atas memberi arti bahwa KPK sebagai salah satu lembaga negara dalam sistem ketatanegaraan adalah konstitusional dan dibentuk karena adanya realita yang terjadi bahwa saat ini masalah korupsi di Indonesia merupakan masalah yang sangat penting untuk diberantas dan diprioritaskan penanganannya sehingga diperlukan suatu lembaga negara bantu seperti KPK menangani dan memberantas masalah korupsi. ${ }^{20}$ KPK sebagai lembaga pemberantas korupsi yang diberikan kewenangan yang kuat bukan berada di luar sistem ketatanegaraan, namun ditempatkan secara yuridis di dalam sistem ketatanegaraan yang rangka dasarnya sudah ada di dalam UUD 1945. KPK juga tidak mengambil alih kewenangan lembaga lain, melainkan diberi atau mendapat kewenangan dari pembuat UU sebagai bagian dari upaya melaksanakan perintah UUD 1945 di bidang penegakan hukum, peradilan, dan kekuasaan kehakiman.

\section{Kesimpulan}

Munculnya lembaga-lembaga negara yang bersifat independen seperti Komisi Nasional Hak Asasi Manusia (Komnas HAM) dan Komisi Pemberantasan Tindak Pidana Korupsi (KPK) menggambarkan bahwa adanya kebutuhan untuk mengatasi persoalan-persoalan kemasyarakatan yang semakin tidak terbendung. Hal ini disebabkan karena adanya perkembangan yang semakin kompleks, organisasi kekuasaan yang birokratis, sentralistis, dan terkonsentrasi yang tidak dapat diunggulkan. Munculnya lembaga-lembaga baru yang memiliki derajat yang sejajar dengan lembaga yang disebutkan dalam konstitusi (Constitusional Importance) berguna untuk menjalankan fungsi-fungsi yang bersifat campuran dan masing-masing bersifat independen (Independent Bodies) yang fokusnya pada bidangnya masing-masing. Misalnya lembaga Komisi Nasional Hak Asasi Manusia (Komnas HAM) yang fungsinya lebih dekat ke fungsi perjuangan aspirasi seperti Dewan Perwakilan Rakyat (DPR) namun sekaligus dekat dengan fungsi pengadilan. Sedangkan kewenangan KPK lebih difokuskan pada penyelidikan, penyidikan, dan penuntutan tindak pidana korupsi.

\section{Daftar Pustaka}

A. Buku

Jimly Asshiddiqie, Perkembangan dan Konsolidasi Lembaga Negara Pasca Reformasi, Jakarta: Sinar Grafika, 2012.

B. Jurnal

Bustamin, Bustamin, and Rony Jaya. "Urgensi Checks And Balances Ketatanegaraan Indonesia Dan Islam.” JURIS (Jurnal Ilmiah Syariah) 18, no. 2, 2019: 221-32. https://doi.org/10.31958/juris.v18i2.1740.

\footnotetext{
${ }^{19}$ Yopa Puspitasari, "Kedudukan Komisi Pemberantasan Korupsi (Kpk) Dalam Struktur Ketatanegaraan Indonesia Ditinjau Dari Hukum Islam," AL IMARAH: JURNAL PEMERINTAHAN DAN POLITIK ISLAM 4, no. 2 (2019): 163-76, https://doi.org/10.29300/imr.v4i2.2830.

20 Roy Saphely, Keberadaan Komisi Pemberantasan Korupsi Dalam Sistem Ketatanegaraan Dan Implikasinya Terhadap Kewenangan Kejaksaan Dan Kepolisian Republik Indonesia, Bagian Hukum Dinas PUPR Kab. Bandung, hlm. 82.
} 
Efriza. "Relasi Kekuasaan Presiden Dan DPR Dalam Sistem Presidensial Power Relations President And Parliament In The Presidential System.” Jurnal Kajian Politik Dan Masalah Pembangunan, 2016.

Habibi, Muhammad. "Independensi Kewenangan Komisi Pemberantasan Korupsi Pasca Perubahan Undang-Undang Nomor 30 Tahun 2002 Tentang Komisi Pemberantasan Korupsi." Cepalo 4, no. 1, 2020: 38-47. https://doi.org/10.25041/cepalo.v4no1.1962.

Jailani. "Sistem Demokrasi Di Indonesia Ditinjau Dari Sudut Hukum Dan Ketatanegaraan." Sistem Demokrasi,Sudutt Hukum,Ketatanegaraan 8, no. 1, 2015: 134-47.

Jimly Asshiddiqie, 2003, Struktur Ketatanegaraan Indonesia Setelah Perubahan Keempat UUD Tahun 1945, makalah disampaikan dalam simposium yang diselenggarakan oleh Badan Pembinaan Hukum Nasional, Departemen Kehakiman dan HAM.

Marlina, Rika. "Summary For Policymakers." In Climate Change 2013 - The Physical Science Basis, edited by Intergovernmental Panel on Climate Change, 1:1-30. Cambridge: Cambridge University Press, 2018. https://doi.org/10.1017/CBO9781107415324.004.

Mawarini Sukmariningsih, Retno. "Penataan Lembaga Negara Mandiri Dalam Struktur Ketatanegaraan Indonesia." Mimbar Hukum - Fakultas Hukum Universitas Gadjah Mada 26, no. 2, 2014: 194-204. https://doi.org/10.22146/jmh.16039.

Puspitasari, Yopa. "Kedudukan Komisi Pemberantasan Korupsi (Kpk) Dalam Struktur Ketatanegaraan Indonesia Ditinjau Dari Hukum Islam." AL IMARAH: JURNAL PEMERINTAHAN DAN POLITIK ISLAM 4, no. 2, 2019: 163-76. https://doi.org/10.29300/imr.v4i2.2830.

Putra, Muhammad Amin. "Eksistensi Lembaga Negara Dalam Penegakan Hak Asasi Manusia Di Indonesia.” FIAT JUSTISIA:Jurnal Ilmu Hukum 9, no. 3, April 19, 2016: 256-92. https://doi.org/10.25041/fiatjustisia.v9no3.600.

Rahmatullah, Indra, and Rizza Zia Agusty. "Memperkuat Hubungan Antar Lembaga Negara Dalam Bingkai Negara Hukum.” SALAM: Jurnal Sosial Dan Budaya Syar-I 3, no. 2, 2016: 231-44. https://doi.org/10.15408/sjsbs.v3i2.7856.

Ramadani, Rizki. "Lembaga Negara Independen Di Indonesia Dalam Perspektif Konsep Independent Regulatory Agencies." Jurnal Hukum Ius Quia Iustum 27, no. 1, 2020: 169-92. https://doi.org/10.20885/iustum.vol27.iss1.art9.

Rishan, Idul. "Relevansi Hak Angket Terhadap Komisi Negara Independen." Dialogia Iuridica: Jurnal Hukum Bisnis Dan Investasi 10, no. 1, 2018: 44-64. https://doi.org/10.28932/di.v10i1.1031.

Sailan, Manan. "Istilah Negara Hukum Dalam Sistem Ketatanegaraan Republik Indonesia." Istilah Negara Hukum Dalam Sistem Ketatanegaraan Republik Indonesia 40, no. 2, 2011: 228-35. https://doi.org/10.14710/mmh.40.2.2011.228-235.

Soemarsono, Maleha. "Negara Hukum Indonesia Ditinjau Dari Sudut Teori Tujuan Negara." Jurnal Hukum \& Pembangunan 37, no. 2, 2017: 300-322. https://doi.org/10.21143/jhp.vol37.no2.1480.

Thalhah, HM. "Teori Demokrasi Dalam Wacana Ketatanegaraan Perspektif Pemikiran Hans Kelsen." JURNAL HUKUM IUS QUIA IUSTUM 16, no. 3, 2009: 413-22. https://doi.org/10.20885/iustum.vol16.iss3.art6.

Yani, Ahmad. "Sistem Pemerintahan Indonesia: Pendekatan Teori Dan Praktek Konstitusi Undang-Undang Dasar 1945." Jurnal Ilmiah Kebijakan Hukum 12, no. 2, 2018: 119-35. https://doi.org/10.30641/kebijakan.2018.V12.119-135. 
